\title{
Alcohol dehydrogenase 1C (ADH1C) polymorphism is significantly associated with kidney function status in Nusa Tenggara Timur ethnicity: A cross-sectional study
}

\author{
Budiatri Retno Noormaningrum ${ }^{1 *}$, Yudha Nurhantari1, Suhartini', Tri Ratnaningsih², Maria Agnes \\ Etty Dedy ${ }^{3,4}$ \\ ${ }^{1}$ Department of Forensic and Legal Medicine, Faculty of Medicine, Public Health, and Nursing, Universitas Gadjah Mada, \\ Yogyakarta, Indonesia \\ ${ }^{2}$ Department of Clinical Pathology and Laboratory Medicine, Faculty of Medicine, Public Health, and Nursing, Universitas \\ Gadjah Mada, Yogyakarta, Indonesia \\ ${ }^{3}$ Department of Anesthesiology \& Intensive care, General Hospital Prof.Dr. W.Z. Johannes Kupang, Indonesia \\ ${ }^{4}$ Faculty of Medicine, University of Nusa Cendana, Kupang, Indonesia
}

KEYWORDS

ADH1C

polymorphism

Alcohol

dehydrogenase

Glomerular filtration rate

\begin{abstract}
Excessive alcohol consumption is harmful to many human organs, but the association with kidney function is still controversial. The disagreement in findings might be caused by $A D H 1 C$ polymorphism's influence on alcohol metabolism rate. This study aims to determine the correlation between $A D H 1 C$ polymorphism and kidney function status in Nusa Tenggara Timur (NTT) ethnicity, a population with highly prevalent alcohol consumption in Indonesia. We conducted a cross-sectional study of 76 subjects, who are natives of NTT, Indonesia. The genotyping of extracted DNA for ADH1C was done by polymerase chain reaction-restriction fragment length polymorphism (PCR-RFLP) using restriction endonuclease Sspl. Kidney function status was defined by serum urea level and estimated glomerular filtration rate (eGFR) that had been categorized according to percentiles. The correlation with the ADH1C allele was analyzed using chi-square tests. The genotype of ADH1C in NTT ethnicity was $A D H 1 C^{*} 1 /{ }^{*} 2(51.3 \%), A D H 1 C^{*} 2 /{ }^{*} 2$ (47.4\%) and $A D H 1 C^{*} 1 /{ }^{*} 1$ (1.3\%). The results showed that the population had the $A D H 1 C^{\star} 2(73.03 \%)$ and the $A D H 1 C^{\star} 1(26.97 \%)$ allele. There was a significant association between ADH1C polymorphism and eGFR among NTT ethnicity $(p=0.005)$ when eGFR was analyzed at the $25^{\text {th }}$ percentile $\left(74.75 \mathrm{~mL} /\right.$ minute $\left./ 1.73 \mathrm{~m}^{2}\right)$. However, we found no associations when eGFR was analyzed at $50^{\text {th }}(p=0.571)$ and $75^{\text {th }}$ $(p=0.335)$ percentiles. The odds ratio shows that having the $A D H 1 C^{*} 1 /{ }^{*} 2$ genotype escalates the probability of declining eGFR 6.620 times compared to $A D H 1 C * 2 /{ }^{*} 2$ (95\% Cl: $\left.1.539-28.478\right)$, after adjusted for smoking behavior. We found no association between ADH1C polymorphism and serum urea level $(p=0.123,0.421$, and 0.335$)$. The majority of NTT ethnicity have the $A D H 1 C^{*} 1 /{ }^{*} 2$ genotype. Populations with $A D H 1 C^{*} 1 /{ }^{*} 2$ have higher odds ratio for eGFR below $74.75 \mathrm{~mL} /$ minute $/ 1.73 \mathrm{~m}^{2}$ than those with $A D H 1 C * 2 / 2$ genotype. There was no association between $A D H 1 C$ polymorphism and serum urea levels.
\end{abstract}

(C) The Journal 2021. This article is distributed under a Creative Commons Attribution-ShareAlike 4.0 International license.

\section{Introduction}

Decreased kidney function, although minor, could lead to worsening of patient outcomes in some particular conditions. ${ }^{1}$ This alteration could progress to chronic kidney disease (CKD), or even to chronic kidney failure. ${ }^{2}$ In Indonesia, data from 2017 showed that hemodialysis therapy for chronic kidney failure

\footnotetext{
*Correspondence: retno_noormaningrum@ugm.ac.id Department of Forensic and Legal Medicine, Faculty of Medicine, Public Health, and Nursing, Universitas Gadjah Mada, Jl. Farmako, Sekip Utara, Yogyakarta 55281, Indonesia
}

had financially burdened the country enormously, equal to more than USD $\$ 200,000,000$ in a given year. $^{3}$

One of the factors that could affect kidney function is alcohol consumption. Alcohol abuse is the cause of more than $3,000,000$ deaths annually. ${ }^{4}$ In Indonesia, more than 800,000 people consumed alcohol in 2018, and Nusa Tenggara Timur (NTT) had the highest number of excessive alcohol consumption rate. $^{5}$ Home-made liquor that is traditionally produced remains essential parts in many rituals in NTT. ${ }^{6}$ 
The effect of alcohol on kidney function is still controversial. A meta-analysis study showed that alcohol had a protective effect on the kidney, while another study showed that excessive alcohol consumption could lead to kidney hyperfiltration, an early marker of kidney problems. ${ }^{8}$ We need to define the factors that affect the kidney vulnerability towards alcohol, so the results could be emphasized in the educational programs regarding alcohol preventative measures in society. One of the factors that we presume can vary human body responses to alcohol consumption is the $A D H 1 C$ polymorphism, the gene that encodes the $A D H 1 C$ enzyme that has a major role in alcohol metabolism, ${ }^{9}$ by directly influencing the alcohol metabolism rate. Polymorphism is linked to ethnicity, and there is still no study on the correlation of $A D H 1 C$ polymorphism to kidney function status in the particular NTT ethnicity previously published. Therefore, we conducted this study among the NTT ethnic group, a highly prevalent alcohol consumption population in Indonesia.

\section{Method}

This cross-sectional study was conducted in Bakunase, Kupang, NTT province in Indonesia, in October 2019. This sub-district was chosen because of the easy access and coordination with the local community health center. All of the subjects enrolled were above 18 years old and belonged to indigenous NTT ethnicity, which was proved by his or her past three generations who all lived in NTT. The subjects were recruited and screened for the inclusion criteria by the local community health center. Approval of this study was given by the Medical and Health Research Ethics Committee of Faculty of Medicine, Public Health and Nursing at Universitas Gadjah Mada (letter number KE/FK/0830/EC/2019). Informed consent was obtained from every subject. We excluded subjects who were undergoing dialysis therapy or suffered from severe kidney-related diseases. Information regarding health conditions and smoking habits was gained from the subjects' interviews.

Seven milliliters of venous blood were drawn from 76 subjects, and divided into 2 vacutainers. The first vacutainer was a serum-separator tube. The blood was utilized to assess the serum creatinine and urea levels, using an automatic chemistry analyzer (Cobas ${ }^{\circledR}$ 6000, Roche, Rotkreuz, Switzerland). The second vacutainer was coated with ethylenediaminetetraacetic acid (EDTA). The blood in the second vacutainer was prepared for DNA analysis. DNA was isolated using a Wizard ${ }^{\circledR}$ Genomic DNA Purification Kit (Promega, Madison, Wisconsin, USA). The integrity and purity of isolated DNA were checked by a nano spectrophotometer with the expected result of A260:A280 with around 1.8. Genotyping was done using the PCRRFLP method as previously described with some modifications. ${ }^{10}$ The recognition sequences were: ADH3321 (5'-GCTTTAAGAGTAAATATTCTGTCC-3') and ADH3351 (5'-AATCTACCTCTTTCCAGAGC-3') as forward and reverse primers, respectively. PCR was performed using a $30 \mu \mathrm{l}$ reaction mixture, comprised of $3 \mu \mathrm{l}$ isolated DNA, $15 \mu \mathrm{l}$ of the DreamTaq Green PCR master mix (Thermo Fisher, Massachusetts, USA) , $8 \mu$ l of water, and $2 \mu$ l of each primer. The PCR conditions involved initial denaturation at $95^{\circ} \mathrm{C}$ for $5 \mathrm{~min}$, followed by 34 cycles of denaturation, annealing, and elongation at $94^{\circ} \mathrm{C}$ for $1 \mathrm{~min}, 55^{\circ} \mathrm{C}$ for $1 \mathrm{~min}$, and $72^{\circ} \mathrm{C}$ for $1 \mathrm{~min}$. The last step was the final elongation at $72^{\circ} \mathrm{C}$ for $10 \mathrm{~min}$. PCR product was then digested with FastDigest ${ }^{\text {TM }}$ Sspl kit (Thermo Fisher, Massachusetts, USA) that has recognition site at $5^{\prime}$...AAT*ATT...3' and $3^{\prime}$...TTA*TAA...5' for forward and reverse primer, respectively. The incubation was done at $37^{\circ} \mathrm{C}$ for $20 \mathrm{~min}$. The product then underwent an electrophoresis process and visualized under UV light. The $A D H 1 C^{*} 1 /{ }^{*} 1$ shows an undigested band at $146 \mathrm{bp}$, the $A D H 1 C^{*} 1{ }^{*} 2$ shows three bands at 146 , 83 , and $63 \mathrm{bp}$, and $A D H 1 C^{*} 2 /{ }^{*} 2$ shows two bands at 83 and $63 \mathrm{bp}$.

Genotypic frequencies were calculated and crude odds ratios (OR) were determined using chisquare tests with $95 \%$ confidence intervals $(\mathrm{Cl})$ if the requirements were met. The alternatives were the Fisher exact or Kruskal-Wallis tests. Kidney function status was analyzed according to $25^{\text {th }}, 50^{\text {th }}$, and $75^{\text {th }}$ percentiles of eGFR and serum urea levels.

Estimated GFR was calculated based on serum creatinine levels using the Chronic Kidney Disease Epidemiology Collaboration (CKD-EPI) equation. To determine the effect modifiers or confounding 
variables involved bivariate analysis (chi-square) to suggest potential variables, continued with multivariate analysis using logistic regression to adjust the OR.

\section{Result}

Among 76 study subjects, the most frequent genotype was $A D H 1 C^{*} 1 /{ }^{*} 2$ (51.3\%), followed by $A D H 1 C^{*} 2 /{ }^{*} 2$ (47.4\%) and $A D H 1 C^{*} 1 /{ }^{*} 1$ (1.3\%), respectively. Hence, the majority of the population had the $A D H 1 C^{*} 2$ allele (73.03\%) (Table 1). There was no statistically significant difference between observed and expected results of genotype distribution were according to the Hardy-Weinberg equilibrium equation ( $p=0.653$ ).

The demographical and clinical characteristics that consisted of sex, age, body mass index (BMI), smoking habit, and hypertension were similar between $A D H 1 C^{*} 1 /^{*} 2$ and $A D H 1 C^{*} 2{ }^{*} 2$ groups. $A$ comparison could not be made between $A D H 1 C * 1 /{ }^{*} 1$ with other $A D H 1 C$ genotypes because there was only 1 subject in the group (Table 2 ).
There was a significant association between $A D H 1 C$ genotype and eGFR when analyzed at the $25^{\text {th }}$ percentile $(p=0.005)$, which was at $74.75 \mathrm{ml} /$ $\mathrm{min} / 1.73 \mathrm{~m}^{2}$ (Table 3 ). When $A D H 1 C^{*} 2{ }^{*} 2$ was used as a reference genotype, only $A D H 1 C^{*} 1 /{ }^{*} 2$ was correlated significantly, with a crude OR of 4.480 (95\% Cl: 1.312-15.299) (Table 4). After adjusted for smoking habit, having $A D H 1 C^{*} 1 /{ }^{*} 2$ showed an OR of 6.620 compared to $A D H 1 C * 2 / * 2(95 \% \mathrm{Cl}$ : 1.539 28.478). Smoking habit modified the association with an OR of 0.191 (95\% Cl: 0.051-0.708).

There were no significant results concerning the correlation between $A D H 1 C$ and eGFR when assessed at the $50^{\text {th }}(p=0.571)$ and $75^{\text {th }}$ percentiles $(p=0.335)$, which were at $92.90 \mathrm{ml} / \mathrm{min} / 1.73 \mathrm{~m}^{2}$, and $116.82 \mathrm{ml}$ $\mathrm{min} / 1.73 \mathrm{~m}^{2}$, respectively (Table 3 ). There were no associations between $A D H 1 C$ and serum urea levels, in all percentiles (Table 5).

\section{Discussion}

The most frequent $A D H 1 C$ genotype in this study was the heterozygote polymorphic type, that has similarity with Papua ethnicity that is a Melanesian

Table 1. Genotype distribution and allele frequency of $A D H 1 C$ in NTT ethnicity

\begin{tabular}{llll}
\hline Genotype & $\mathbf{n}(\%)$ & Allele & $\mathbf{n}(\%)$ \\
\hline$A D H 1 C^{*} 1{ }^{*} 1$ & $1(1.3)$ & $A D H 1 C^{*} 1$ & $41(26.97)$ \\
$A D H 1 C^{*} 1 /^{* 2}$ & $39(51.3)$ & $A D H 1 C^{*} 2$ & $111(73.03)$ \\
$A D H 1 C^{*} 2 /^{*} 2$ & $36(47.4)$ & & \\
\hline Total & $76(100)$ & & $152(100)$ \\
\hline
\end{tabular}

Table 2. Demographical and clinical characteristics of NTT ethnicity according to ADH1C genotype

\begin{tabular}{|c|c|c|c|}
\hline Characteristics & $\begin{array}{l}\text { ADH1C } \\
{ }^{*} 1{ }^{* 1} \\
n(\%)\end{array}$ & $\begin{array}{l}{ }^{*} 1{ }^{*} 2 \\
\mathrm{n}(\%)\end{array}$ & $\begin{array}{l}{ }^{*} 2 /{ }^{* 2} \\
n(\%)\end{array}$ \\
\hline $\begin{array}{l}\text { Sex } \\
\text { Male, } n=57 \\
\text { Female, } n=19\end{array}$ & $\begin{array}{l}1(100) \\
0(0)\end{array}$ & $\begin{array}{l}28(71.8) \\
11(28.2)\end{array}$ & $\begin{array}{l}28(77.8) \\
8(22.2)\end{array}$ \\
\hline $\begin{array}{l}\text { Age (years old) } \\
<22, n=31 \\
\geq 22, n=45\end{array}$ & $\begin{array}{l}0(0) \\
1(100)\end{array}$ & $\begin{array}{l}14(35.9) \\
25(64.1)\end{array}$ & $\begin{array}{l}17(47.2) \\
19(52.8)\end{array}$ \\
\hline $\begin{array}{l}\text { BMI }\left(\mathrm{kg} / \mathrm{m}^{2}\right) \\
<25, \mathrm{n}=56 \\
\geq 25, \mathrm{n}=20\end{array}$ & $\begin{array}{l}1(100) \\
0(0)\end{array}$ & $\begin{array}{l}29(74.4) \\
10(25.6)\end{array}$ & $\begin{array}{l}26(72.2) \\
10(27.8)\end{array}$ \\
\hline $\begin{array}{l}\text { Cigarette Smokin } \\
\text { Yes, } n=45 \\
\text { No, } n=31\end{array}$ & $\begin{array}{l}1(100) \\
0(0)\end{array}$ & $\begin{array}{l}24(61.5) \\
15(38.5)\end{array}$ & $\begin{array}{l}20(55.6) \\
16(44.4)\end{array}$ \\
\hline $\begin{array}{l}\text { Hypertension } \\
\text { Yes, } n=19 \\
\text { No, } n=57\end{array}$ & $\begin{array}{l}0(0) \\
1(100)\end{array}$ & $\begin{array}{l}9(23.1) \\
30(76.9)\end{array}$ & $\begin{array}{l}10(27.8) \\
26(72.2)\end{array}$ \\
\hline
\end{tabular}


Table 3. The association between $A D H 1 C$ genotype and eGFR

\begin{tabular}{|c|c|c|c|c|}
\hline \multirow[t]{2}{*}{$A D H 1 C$} & \multirow[t]{2}{*}{$n$} & \multicolumn{2}{|l|}{ eGFR-25 } & \multirow[t]{2}{*}{$p$} \\
\hline & & $\begin{array}{l}<74.75 \\
n(\%)\end{array}$ & $\begin{array}{l}\geq 74.75 \\
n(\%)\end{array}$ & \\
\hline$* 1 / * 1$ & 1 & $1(100)$ & $0(0)$ & 0.005 \\
\hline$* 1 / * 2$ & 39 & $14(35.9)$ & $25(64.1)$ & \\
\hline$* 2 / * 2$ & 36 & 4 (11.1) & $32(88.9)$ & \\
\hline \multirow[t]{2}{*}{ ADH1C } & \multirow[t]{2}{*}{$n$} & eGFR-50 & & \multirow[t]{2}{*}{$p$} \\
\hline & & $\begin{array}{l}<92.90 \\
n(\%)\end{array}$ & $\begin{array}{l}\geq 92.90 \\
\mathrm{n}(\%)\end{array}$ & \\
\hline$* 1 /{ }^{*} 1$ & 1 & $1(100)$ & $0(0)$ & 0.571 \\
\hline$* 1 / * 2$ & 39 & $20(51.3)$ & $19(48.7)$ & \\
\hline$* 2 / * 2$ & 36 & $17(47.2)$ & $19(52.8)$ & \\
\hline \multirow[t]{2}{*}{$A D H 1 C$} & \multirow[t]{2}{*}{$n$} & eGFR-75 & & \multirow[t]{2}{*}{$p$} \\
\hline & & $\begin{array}{l}<116.82 \\
\mathrm{n}(\%)\end{array}$ & $\begin{array}{l}\geq 116.82 \\
\mathrm{n}(\%)\end{array}$ & \\
\hline$* 1 /{ }^{*} 1$ & 1 & $1(100)$ & $0(0)$ & 0.335 \\
\hline$*^{1} /{ }^{*} 2$ & 39 & $27(69.2)$ & $12(30.8)$ & \\
\hline$* 2 / * 2$ & 36 & $29(80.6)$ & 7 (19.4) & \\
\hline
\end{tabular}

Table 4. The crude odds ratio of $A D H 1 C$ genotype in correlation with eGFR-25

\begin{tabular}{|c|c|c|c|c|c|}
\hline \multirow[b]{2}{*}{ ADH1C } & \multirow[b]{2}{*}{$\mathbf{n}$} & \multicolumn{2}{|l|}{ eGFR-25 } & \multirow[b]{2}{*}{$p$} & \multirow[b]{2}{*}{ Crude OR } \\
\hline & & $\begin{array}{l}<74.75 \\
n(\%)\end{array}$ & $\begin{array}{l}\geq 74.75 \\
n(\%)\end{array}$ & & \\
\hline$* 1 / * 1$ & 1 & $1(100)$ & $0(0)$ & $0,135^{1}$ & - \\
\hline$* 1 / * 2$ & 39 & $14(35.9)$ & $25(64.1)$ & $0,012^{2}$ & 4.480 \\
\hline$* 2 / * 2$ & 36 & 4 (11.1) & 32 (88.9) & Ref. & Ref. \\
\hline
\end{tabular}

racial profile. ${ }^{11}$ The genotype that was also widely found in NTT ethnicity was $A D H 1 C^{*} 2 / * 2$. This homozygote polymorphic type is considered the majority genotype in Javanese ethnicity, an Austronesian racial profile. Java ethnicity also has ADH $1 C^{*} 2$ alleles dominating, as found in this study. ${ }^{10}$ These comparable findings might be due to modern human migration in ancient times. Nusa Tenggara Timur ethnicity in their ancestors were derived from transethnic interactions of Austronesian peoples that came from western and Melanesian peoples from eastern regions of Indonesia who gave rise to the Austro-Melanesian racial profile of the indigenous NTT ethnicity. ${ }^{12}$ These findings were different from studies that were conducted in Europe and China that showed $A D H 1 C^{*} 1$ is the most frequent allele carried by the populations. ${ }^{13,14}$

The genotype distribution in NTT ethnicity was in the Hardy-Weinberg equilibrium. Therefore, we conclude that our study subjects met the HardyWeinberg equilibrium assumptions, to wit: random mating, and no genetic mutations nor natural selections happened. ${ }^{15}$

The demographical and clinical characteristics that consisted of sex, age, BMI, smoking habit, and hypertension had balanced distribution between $A D H 1 C^{*} 1 /{ }^{*} 2$ and $A D H 1 C^{*} 2 /{ }^{*} 2$ groups. Hence, these two groups were comparable. We could not include $A D H 1 C^{*} 1 /{ }^{*} 1$ in the comparison due to the lack of subjects in the mentioned group.

Kidney function status in this study was presented in the declining eGFR and elevating serum urea levels 
Table 5. The association between $A D H 1 C$ genotype and serum urea levels

\begin{tabular}{|c|c|c|c|c|}
\hline \multirow[b]{2}{*}{ ADH1C } & \multirow[b]{2}{*}{$\mathbf{n}$} & \multicolumn{2}{|c|}{ Serum Urea Level-25 } & \multirow[b]{2}{*}{$\mathbf{p}$} \\
\hline & & $\begin{array}{l}\geq 20.1 \\
\mathrm{n}(\%)\end{array}$ & $\begin{array}{l}<20.1 \\
\mathrm{n}(\%)\end{array}$ & \\
\hline$* 1 / * 1$ & 1 & $1(100)$ & $0(0)$ & $0.123^{1}$ \\
\hline$* 1 / * 2$ & 39 & $11(28.2)$ & $28(71.8)$ & \\
\hline$* 2 / * 2$ & 36 & $6(16.7)$ & $30(83.3)$ & \\
\hline
\end{tabular}

\begin{tabular}{lllll}
\hline \multirow{2}{*}{$\boldsymbol{A D H 1 C}$} & $\mathrm{n}$ & \multicolumn{2}{l}{ Serum Urea Level-50 } & \\
\cline { 3 - 5 } & & $\begin{array}{l}\geq \mathbf{2 9 . 1} \\
\mathbf{n}(\%)\end{array}$ & $\begin{array}{l}<\mathbf{2 9 . 1} \\
\mathbf{n}(\%)\end{array}$ & $\boldsymbol{p}$ \\
\hline$*^{*} 1 /{ }^{* 1}$ & 1 & $1(100)$ & $0(0)$ & $0.421^{1}$ \\
$*^{*} 1 /{ }^{2}$ & 39 & $20(51.3)$ & $19(48.7)$ & \\
$*^{*} 2 /{ }^{2}$ & 36 & $16(44.4)$ & $20(55.6)$ &
\end{tabular}

\begin{tabular}{|c|c|c|c|c|}
\hline \multirow[b]{2}{*}{$A D H 1 C$} & \multirow[b]{2}{*}{$\mathbf{n}$} & \multicolumn{2}{|c|}{ Serum Urea Level-75 } & \multirow[b]{2}{*}{$p$} \\
\hline & & $\begin{array}{l}\geq 36.1 \\
n(\%)\end{array}$ & $\begin{array}{l}<36.1 \\
\mathrm{n}(\%)\end{array}$ & \\
\hline$* 1 / * 1$ & 1 & $1(100)$ & $0(0)$ & $0.335^{1}$ \\
\hline$*_{1} / *_{2}$ & 39 & $27(69.2)$ & $12(30.8)$ & \\
\hline$* 2 / * 2$ & 36 & $29(80.6)$ & $7(19.4)$ & \\
\hline
\end{tabular}

Serum urea levels are in mg/dl. ${ }^{1}$ By Kruskal Wallis test.

that were analyzed at $25^{\text {th }}, 50^{\text {th }}$, and $75^{\text {th }}$ percentiles. The only significant association was found between ADH1C genotype and eGFR while analyzed at the $25^{\text {th }}$ percentile (eGFR below $74.75 \mathrm{ml} / \mathrm{min} / 1.73 \mathrm{~m}^{2}$ ). Estimated GFR less than $74 \mathrm{ml} / \mathrm{min} / 1.73 \mathrm{~m}^{2}$ has increased mortality rate in populations at risk if albumin-to-creatinine urine ratio was more than 30 $\mathrm{mg} / \mathrm{g} .{ }^{16}$

Crude OR of 4.480 was generated from comparing $A D H 1 C^{*} 1 /{ }^{*} 2$ to $A D H 1 C * 2 / * 2$ for declining eGFR at the $25^{\text {th }}$ percentile. To ensure there were no confounding or effect modifier variables, bivariate and multivariate analyses were done on all of the external variables. The OR was adjusted for smoking habit and yielded 6.620 times the probability of having declining eGFR below $74.75 \mathrm{ml} / \mathrm{min} / 1.73 \mathrm{~m}^{2}$ for $A D H 1 C^{*} 1 / * 2$ compared to $A D H 1 C^{*} 2 / * 2$ carriers.

This finding is probably due to the heterodimer ADH1C enzyme that is encoded by $A D H 1 C^{*} 1 /{ }^{*} 2$. This enzyme has $\gamma_{1}$ subunit with a faster alcohol to acetaldehyde metabolism rate compared to the $\gamma_{2}$ subunit, which is encoded by the $A D H 1 C^{*} 2$ allele. ${ }^{17}$ The faster metabolism rate increases the acetaldehyde accumulation risk, although slower acetaldehyde to acetate metabolism rate is needed for this accumulation to occur. Acetaldehyde, which is toxic, could induce some pathogenic symptoms, ${ }^{18}$ and is suspected to harm the kidney. Previous studies found that having $A D H 1 C^{*} 1$ allele increased the risk for liver cirrhosis, alcoholic pancreatitis, and breast cancer in the alcoholic population. ${ }^{19,20}$

Smoking habit was an effect modifier variable in this study. The inverse OR between smoking habit and declining eGFR could be related to the previous study by Wang et al. This study adduced that smokers had larger kidney volume. ${ }^{21}$ However, to conclude that smoking has beneficial value towards kidney function should not be recklessly made. A 10-year interval cohort study in living kidney donor populations found that smoking lowered postoperative eGFR, thus it increased chronic kidney disease risk. ${ }^{22}$

There was no association between ADH1C polymorphism and serum urea level, as found in an animal study that compared alcohol consumption and serum urea levels. ${ }^{23}$ On the other hand, the previous study in humans showed that drinkers tended to have higher serum urea levels, ${ }^{24}$ though our study suggests that this association is not correlated to $A D H 1 C$ polymorphism.

The statistically insignificant result might occur because serum urea level is an unreliable indicator in kidney function status since it is easily changed by internal and external factors, i.e. protein intake, muscle catabolism, and limited blood absorption from gastrointestinal tract bleeding. ${ }^{25}$ Therefore, we recommend a more accurate kidney function indicator, such as serum cystatin c levels or moreover, radioisotope markers.

However, our study had some limitations in the sampling methods. We suggest using a larger sample size in the next research regarding $A D H 1 C$ in the NTT ethnic group so that subjects in the $A D H 1 C^{*} 1 /{ }^{*} 1$ group possibly meet the minimal sample size to be analyzed. This study also could be improved with the random sampling method so that it could accurately represent the actual population.

\section{Conclusions}

This study found that the majority of ethnic NTT have the $A D H 1 C^{*} 1 /{ }^{*} 2$ genotype. Having $A D H 1 C^{*} 1 /{ }^{*} 2$ 
tended to have 6.620 times lower eGFR when the cut-off was at $74.75 \mathrm{ml} / \mathrm{min} / 1.73 \mathrm{~m}^{2}$ compared to $A D H 1 C^{*} 2 /{ }^{*} 2$, after adjusted for the smoking habit. This study showed the genetic vulnerability of alcohol-related declining kidney function in most of the ethnic NTT population. Hopefully, these results will provide an evidence-based stimulus to encourage alcohol cessation or moderation in the NTT population.

\section{Acknowledgement}

This research was part of a collaborative research titled: Hubungan antara Polimorfisme Gen $A D H 2$, CYP450EI dan ALDH2 dengan Kadar Enzim Liver pada Peminum Alkohol Orang Papua dan Nusa Tenggara Timur and was presented at a Second Conference on Community Empowerment for Health, Yogyakarta, November 28, 2020. This research received a grant from the Sistem Informasi Manajemen Penelitian dan Pengabdian kepada Masyarakat (Simlitabmas), Penelitian Dasar Unggulan Perguruan Tinggi, Ministry of Research and Technology of Indonesia (letter number 45/UN1/DITLIT/DIT-LIT/LT/2018).

\section{Conflict of interests}

The authors declare that they have no conflict of interests.

\section{References}

1. Lassnigg $A$, Schmildlin $D$, Mouhieddine $M$, Bachmann LM, Druml W, Bauer P, et al. Minimal changes of serum creatinine predict prognosis in patients after cardiothoracic surgery: A prospective cohort study. J Am Soc Nephrol [Internet]. 2004 Jun 1;15(6):1597-605. Available from: http://www.jasn.org/cgi/doi/10.1097/01. ASN.0000130340.93930.DD

2. Coca SG, Singanamala S, Parikh CR. Chronic kidney disease after acute kidney injury: $A$ systematic review and meta-analysis. Kidney Int. 2012;81(5):442-8.

3. BPJS. Laporan Pengelolaan Program and Laporan Keuangan Jaminan Sosial Kesehatan Tahun 2017 [Program Management and Financial Report of Social Health Insurance 2017]. 2017;150. Available from: https:// bpjs-kesehatan.go. id/bpjs/dmdocuments/ 5b8c446214547b3f6727a710cd62dae7.pdf

4. Hammer JH, Parent MC, Spiker DA, World Health Organization. Global Status Report on Alcohol and Health. 2018, Vol. 65, 74-85 p.

5. Laporan Nasional Riskesdas [Internet]. Badan Penelitian dan Pengembangan Kesehatan. 2018. Available from: http://labdata.litbang.kemkes. go.id/images/download/laporan/RKD/2018/ Laporan_Nasional_RKD2018_FINAL.pdf

6. Salesman F, Juraman SR, Lette A, Gobang YGD, Rengga MPE. The controversy between the Indonesian government policy and Manggarai's culture value about "sopi" liquor. J Drug Alcohol Res. 2018;7(74).

7. Cheungpasitporn W, Thongprayoon C, Kittanamongkolchai W, Brabec BA, O'corragain $\mathrm{OA}$, Edmonds PJ, et al. High alcohol consumption and the risk of renal damage: A systematic review and meta-analysis. Qjm. 2015;108(7):539-48.

8. Lin $M$, Su $Q$, Huang $H$, Zheng $Y$, Wen J, Yao J, et al. Alcohol consumption and the risk for renal hyperfiltration in the general Chinese population. Eur J Clin Nutr. 2017;71(4):500-5.

9. Seitz HK, Mueller S. Alcohol: Metabolism, Toxicity and Its Impact on Nutrition. Third Edit. Reference Module in Biomedical Sciences. Elsevier; 2014. 1-13 p. Available from: https:// www.sciencedirect.com/science/article/pii/ B9780128012383002294

10. Suhartini, Mustofa, Nurhantari Y, Rianto BUD. The analysis of polymorphism of Alcohol dehydrogenase 3 (ADH3) gene and influence of liver function status in Indonesia. Kobe J Med Sci. 2016;62(4):E107-13.

11. Priyambodo DY. Hubungan antara Polimorfisme Gen ADH3 dengan Perilaku Minum Alkohol pada Mahasiswa Papua di Yogyakarta [master thesis]. Universitas Gadjah Mada; 2018.

12. Cox MP, Karafet TM, Lansing JS, Sudoyo H, Hammer MF. Autosomal and X-linked single nucleotide polymorphisms reveal a steep AsianMelanesian ancestry cline in eastern Indonesia and a sex bias in admixture rates. Proc $R$ Soc $B$ Biol Sci. 2010;277(1687):1589-96.

13. Latella MC, Di Castelnuovo $A$, de Lorgeril $M$, Arnout J, Cappuccio FP, et al. Genetic variation of 
alcohol dehydrogenase type $1 \mathrm{C}(\mathrm{ADH} 1 \mathrm{C})$, alcohol consumption, and metabolic cardiovascular risk factors: Results from the IMMIDIET study. Atherosclerosis. 2009;207(1):284-90.

14. Shen Y, Fan J, Edenberg HJ, Li T, Cui Y, Wang Y, et al. Polymorphism of ADH and ALDH genes among four ethnic groups in China and effects upon the risk for alcoholism. Alcohol Clin Exp Res. 1997;21(7):1272-7.

15. Relethford JH. Human Population Genetics, First Edition. In Wiley \& Sons, Inc.; 2012. p. 23-48.

16. Van Der Velde $M$, Matsushita K, Coresh J, Astor BC, Woodward M, Levey A, et al. Lower estimated glomerular filtration rate and higher albuminuria are associated with all-cause and cardiovascular mortality. A collaborative metaanalysis of high-risk population cohorts. Kidney Int [Internet]. 2011;79(12):1341-52. Available from: http://dx.doi.org/10.1038/ki.2010.536

17. Dasgupta A. Genetic aspects of alcohol metabolism and drinking behavior. In Alcohol: Its Biomarkers. 2015;37-63.

18. Edenberg HJ. The genetics of alcohol metabolism: Role of alcohol dehydrogenase and aldehyde dehydrogenase variants. Alcohol Res Heal. 2007;30(1):5-13.

19. Singh D, Negi TS, Upadhya G, Choudhuri G. Polymorphism of alcohol metabolizing gene ADH3 predisposes to development of alcoholic pancreatitis in North Indian population. Front Mol Biosci. 2015;2(DEC):1-6.

20. Terry MB, Gammon MD, Zhang FF, Knight JA, Wang $Q$, Britton JA, et al. ADH3 genotype, alcohol intake and breast cancer risk. Carcinogenesis. 2006;27(4):840-7.

21. Wang $X$, Vrtiska TJ, Avula RT, Walters LR, Chakkera $\mathrm{HA}$, Kremers WK, et al. Age, kidney function, and risk factors associate differently with cortical and medullary volumes of the kidney. Kidney Int. 2014;85(3):677-85.

22. Yoon $\mathrm{YE}$, Lee $\mathrm{HH}, \mathrm{Na} J \mathrm{C}$, Huh $\mathrm{KH}$, Kim MS, Kim SI, Han WK. Impact of cigarette smoking on living kidney donors. Transplant Proc. 2018;50(4):1029-33.

23. Leal S, Ricardo Jorge DO, Joana B, Maria SS, Isabel SS. Heavy alcohol consumption effects on blood pressure and on kidney structure persist after long-term withdrawal. Kidney Blood Press Res. 2017;42(4):664-75.

24. Suhartini, Widagdo $H$, Wira Agni IA, Nurhantari $Y$. The analysis of cell damage of liver and kidney among alcoholics in Yogyakarta, Indonesia. J Med Sci (Berkala Ilmu Kedokteran). 2019;51(03):24657.

25. Lamb EJ, Jones GRD. 32 - Kidney Function Tests. In: Tietz Textbook of Clinical Chemistry and Molecular Diagnostics [Internet]. Sixth Edit. Elsevier Inc.; 2020. p. 479-517.e16. Available from: http://dx.doi.org/10.1016/B978-0-32335921-4.00032-6 